\title{
Problematika Seleksi dan Rekrutmen Guru Pemerintah di Indonesia
}

\section{Problematic of Selection and Recruitment of Government Teachers in Indonesia}

\author{
Elga Andina ${ }^{1}$ dan Fieka Nurul Arifa ${ }^{2}$ \\ 'elga.andina@dpr.go.id \\ Pusat Penelitian, Badan Keahlian DPR RI \\ Jl. Jenderal Gatot Subroto, Senayan, Jakarta, 10270 \\ 2fieka.arifa@dpr.go.id \\ Pusat Penelitian, Badan Keahlian DPR RI \\ JI. Jenderal Gatot Subroto, Senayan, Jakarta, 10270
}

Naskah diterima: 28 Februari 2021 | Naskah direvisi: 19 Mei 2021 | Naskah diterbitkan: 30 Juni 2021

\begin{abstract}
To date, the implementation of education in Indonesia could not be separated from the problems of teacher governance, non-permanent or honorary teachers, and bureaucratic reforms that affect the quality of education and the working climate within. In an effort to improve the quality of public services by the State Civil Apparatus (ASN), the Ministry of Education and Culture agrees with the Ministry of State Apparatus Utilization and Bureaucratic Reform, as well as the Ministry of Finance to change the recruitment system for government teachers from the recruitment of Candidates for Civil Servants (CPNS) to the recruitment of Government Employees with Work Agreements (PPPK), which in its implementation still leaves several problems with various parties' pros and cons. This qualitative research uses data from related stakeholders meetings with Commission X DPR RI on January 2021, supported by secondary data from mass media and webinars that discuss the issue of PPPK teachers' recruitment to answer the following question: how can teachers' recruitment strategy with PPPK solve the problems of (1) improvement of teachers' management; (2) solving the issue of honorary teachers; and (3) bureaucratic reform by improving the quality of public services by the State Civil Apparatus (ASN)? It can be concluded that there is a need for a total improvement in the teacher selection and recruitment system, namely (1) based on need; (2) candidates are produced by Teachers Training Institution in supply to field's demand; (3) prioritizing competence and qualifications.
\end{abstract}

Keywords: bureaucratic reform; PPPK teachers; selection and recruitment; teacher governance

Abstrak: Penyelenggaraan pendidikan di Indonesia hingga saat ini belum lepas dari persoalan tata kelola guru, guru honorer, dan reformasi birokrasi yang berpengaruh terhadap kualitas pendidikan dan iklim kerja di dalamnya. Dalam upaya peningkatan kualitas layanan publik oleh Aparatur Sipil Negara (ASN), Kementerian Pendidikan dan Kebudayaan sepakat dengan Kementerian Pendayagunaan Aparatur Negara dan Reformasi Birokrasi dan Kementerian Keuangan untuk mengubah sistem rekrutmen guru pegawai pemerintah dari penerimaan Calon Pegawai Negeri Sipil (CPNS) menjadi Pegawai Pemerintah dengan Perjanjian Kerja (PPPK) yang dalam pelaksanaannya 
masih menyisakan beberapa masalah dan pro kontra berbagai pihak. Penelitian kualitatif ini menggunakan data rapat stakeholder terkait dengan Komisi X DPR RI selama bulan Januari 2021 dilengkapi data sekunder dari media massa dan webinar yang membahas mengenai isu rekrutmen guru PPPK guna menjawab pertanyaan: bagaimana strategi rekrutmen guru dengan PPPK dapat menyelesaikan permasalahan

(1) perbaikan tata kelola guru; (2) penyelesaian isu guru honorer; dan (3) reformasi birokrasi dengan peningkatan kualitas layanan publik oleh ASN? Dapat disimpulkan bahwa perlu ada perbaikan total dalam sistem seleksi dan rekrutmen guru, yaitu: (1) berdasarkan kebutuhan; (2) calon guru diproduksi oleh Lembaga Pendidikan Tenaga Kependidikan sesuai dengan kebutuhan di lapangan; dan (3) mengutamakan kompetensi dan kualifikasi.

Kata Kunci: guru PPPK; reformasi birokrasi; seleksi dan rekrutmen; tata kelola guru

\section{Pendahuluan}

Selama lima tahun terakhir, permasalahan ketersediaan guru menjadi semakin memprihatinkan karena upaya pemenuhan guru baru tidak selaras dengan jumlah guru yang pensiun. Moratorium penerimaan Calon Pegawai Negeri Sipil (CPNS) yang dilakukan selama masa pemerintahan Jokowi-JK belakangan dianggap ikut berkontribusi terhadap tidak sehatnya siklus ketenagakerjaan. Kondisi ini mengakibatkan kekurangan guru sampai dengan lima tahun ke depan yang diprediksi mencapai lebih dari satu juta orang guru. Padahal, pemenuhan kebutuhan guru yang profesional merupakan salah satu kunci penyelenggaraan pendidikan yang berkualitas. Selain itu, persebaran guru yang tidak merata akibat perpindahan guru tanpa menyesuaikan kebutuhan daerah juga turut menambah peliknya permasalahan guru.

Data Direktorat Jenderal Guru dan Tenaga Kependidikan (Dirjen GTK) menunjukkan rasio rata-rata perbandingan guru dan siswa adalah 1:16. Saat ini ada 2.906.239 guru yang mengajar di 218.234 sekolah dengan jumlah siswa mencapai 45.073.800 siswa (Badan Pusat Statistik, 2020). Jika dilihat dari angka tersebut, kebutuhan guru sudah terpenuhi karena menurut Kementerian Pendidikan dan Kebudayaan (Kemendikbud), rasio gurusiswa yang ideal bagi Indonesia adalah 1:29 untuk jenjang pendidikan SD, 1:24 untuk SMP, dan 1:20 untuk SMA. Namun kenyataannya, dari keseluruhan guru yang aktif saat ini baru 1.520.354 (52,3\%) guru yang berstatus Pegawai Negeri Sipil (PNS). Sementara itu, $47,7 \%$ sisanya merupakan guru honorer yang terdiri dari 401.182 Guru Tetap Yayasan (GTY/PTY), 13.328 Guru Tidak Tetap (GTT) provinsi, 141.724 GTT kabupaten/kota, 3.770 guru bantu pusat, 704.503 guru honor sekolah, dan 121.378 guru dari kategori lainnya (Kemendikbud, tt).

Semenjak berlakunya Undang-Undang Nomor 13 Tahun 2005 tentang Guru dan Dosen (UUGD), profesi guru menjadi lebih menarik dengan adanya penambahan penghasilan melalui sertifikasi (Ree, Al-Samarrai, \& Iskandar, 2012). Namun, insentif yang diberikan ternyata belum memperlihatkan perubahan pencapaian pendidikan. Hasil Programme for International Student Assessment (PISA) tahun 2018 menunjukkan skor membaca pelajar Indonesia berada di titik terendah selama mengikuti PISA sejak tahun 2000. Siswa dengan kompetensi matematika dasar rendah (di bawah Level 2 dalam skala PISA) berjumlah 71,9\%. Ini menempatkan Indonesia pada peringkat terburuk ke-7 dari 77 negara yang disurvei (Revina \& Huang, 2020). Sementara itu, hasil uji kompetensi guru menunjukkan rata-rata skor kompetensi guru adalah 57 (dari 100). Dapat disimpulkan masih banyak guru yang belum memiliki kompetensi memadai untuk mengajar. Padahal, berbagai penelitian meyakini kualitas guru memengaruhi 
prestasi murid (Rice, 2003; Quin, Hemphill, \& Heerde, 2017; Francis et al., 2019), dan guru yang berkualifikasi belum tentu berkualitas (Xu \& Gulosino, 2006). Tampaknya, secara tidak langsung rendahnya kompetensi guru di Indonesia berkontribusi terhadap rendahnya kemampuan literasi pelajar.

\begin{tabular}{|c|c|}
\hline SD & $54,80 \%$ \\
\hline SMP & $56,60 \%$ \\
\hline
\end{tabular}

SMA

$62,30 \%$

SMK

$58,40 \%$

\section{Bagan 1. \\ Skor Uji Kompetensi Guru \\ Sumber: Ka Balitbang Perbukuan Kemendikbud (2021: 10)}

Patut diduga bahwa rendahnya kualitas guru diawali pada buruknya rekrutmen guru sebagai titik awal pengadaan guru. Menurut Research on Improving Systems of Education (RISE), sistem perekrutan guru yang selama ini dilakukan tidak berorientasi pada kualitas (Revina, 2020). Proses yang berjalan memperlihatkan tidak adanya komitmen pemerintah terhadap sistem perekrutan guru yang efektif, tumpang-tindih kewenangan, adanya pengaruh kepentingan berbagai pihak, dan berkembangnya stigma bahwa status sebagai PNS lebih penting daripada kualitas. Perekrutan guru selalu mengikuti pola penerimaan CPNS secara umum, yang belum tentu cocok dengan natur pekerjaan pendidik. Kelemahan penerimaan CPNS adalah selalu berfokus pada entry level (lulusan baru) dengan penerapan batas usia dan tidak memberikan kesempatan bagi mid-career entry atau bagi mereka yang sudah berada di tengah karir tetapi telah melewati usia 35 tahun. Akibatnya, mereka yang sudah memiliki pengalaman mengajar justru tidak dapat mengikuti seleksi CPNS.
Selain itu, kebutuhan guru selalu ada setiap tahun, tetapi pemerintah daerah (pemda) tidak selalu menawarkan formasi CPNS guru. Akibatnya, sekolah terpaksa merekrut guru honorer untuk memastikan proses pembelajaran tetap berjalan. Dalam laporannya, Asian Development Bank (2021) menyoroti dominannya jumlah guru honorer berpengaruh terhadap bervariasinya distribusi guru karena sangat tergantung pada kemampuan keuangan daerah masing-masing.

Oleh karena itu, pemerintah meyakini seleksi terbuka Pegawai Pemerintah dengan Perjanjian Kerja (PPPK) merupakan langkah strategis dalam pemenuhan kebutuhan tenaga pendidik dan penyelesaian masalah guru honorer. Tentunya pilihan ini harus dijalankan dengan mekanisme yang tepat agar pemenuhan guru tidak hanya merupakan pemenuhan dari sisi status kepegawaian, tetapi juga disertai dengan peningkatan kualifikasi dan kompetensi sesuai dengan bidangnya (Arifa, 2020: 14). Bahkan, Menteri Pendayagunaan Aparatur Negara dan Reformasi Birokrasi (MenPANRB), Menteri Pendidikan dan Kebudayaan (Mendikbud) dan Badan Kepegawaian Negara (BKN) sepakat untuk menghentikan seleksi CPNS guru mulai tahun depan.

Sebagai gantinya, formasi guru akan diisi dengan PPPK. Langkah ini dilakukan untuk: (1) perbaikan tata kelola guru; (2) penyelesaian isu guru honorer; dan (3) reformasi birokrasi dengan peningkatan kualitas layanan publik oleh Aparatur Sipil Negara (ASN) (Kemendikbud, 2021). Keputusan ini mendapat kritikan dari berbagai pihak sehingga Mendikbud, Nadiem Makarim, menjelaskan bahwa pemerintah akan melakukan perekrutan 1 juta guru di tahun 2021, salah satunya melalui skema PPPK. Kepala Badan Kepegawaian Negara $(\mathrm{BKN})$, Bima Haria Wibisana, juga menyatakan tidak menutup kemungkinan akan ada rekrutmen guru untuk formasi CPNS di masa mendatang. Namun, sampai saat ini BKN baru merencanakan proses seleksi melalui PPPK. 
Berdasarkan latar belakang di atas, penelitian kualitatif ini menganalisis kebijakan yang diambil pemerintah mengenai pemenuhan tenaga pendidik melalui PPPK. Oleh karena itu, penelitian ini mengusung pertanyaan penelitian: bagaimana strategi rekrutmen guru dengan PPPK dapat menyelesaikan permasalahan: (1) perbaikan tata kelola guru; (2) penyelesaian isu guru honorer; dan (3) reformasi birokrasi dengan peningkatan kualitas layanan publik oleh ASN?

Dalam penelitian kualitatif ini, data primer diambil dari Rapat Dengar Pendapat Umum (RDPU) Komisi $X$ dengan instansi terkait, yaitu: Kemendikbud, Kementerian Agama (Kemenag), Komite Nusantara Aparatur Sipil Negara (KNASN), Guru dan Tenaga Kependidikan Honorer Non-Kategori Umur 35 Tahun ke Atas (GTKHNK35), Pengurus Pusat Solidaritas Nasional Wiyatabakti Indonesia (SNWI) pada tanggal 13 Januari 2021 yang dapat dapat diakses di https://www.youtube.com/ watch?v=JktUeBIpK3g dan RDPU pada tanggal 18 Januari 2021 dengan Kementerian Dalam Negeri, BKN, Deputi Aparatur Kementerian Pemberdayaan Negara dan Aparatur Sipil Negara, dan Kementerian Pendidikan dan Kebudayaan.

Untuk mendapat gambaran lebih lengkap mengenai kondisi rekrutmen guru ini, peneliti melengkapi informasi yang didapat dengan mengumpulkan berita yang dipublikasikan media massa, serta webinar dan diskusi daring yang membahas rekrutmen guru sebagai data sekunder. Data yang diperoleh dikelompokkan berdasarkan kesamaan ide sehingga peneliti dapat mengklasifikasikan isu-isu penting apa saja yang perlu diperhatikan dalam strategi rekrutmen guru. Tujuan yang ingin dicapai adalah untuk menganalisis manajemen seleksi dan rekrutmen guru yang memengaruhi pola pengelolaan guru secara nasional. Perlu ditekankan juga bahwa penelitian ini hanya membahas seleksi dan rekrutmen guru di sekolah milik pemerintah melalui skema yang dikelola oleh pemerintah.

\section{Seleksi dan Rekrutmen Guru}

Proses penyiapan guru, seleksi, rekrutmen, dan retensi harus dipandang sebagai suatu kontinum karena semua elemen di atas saling berkaitan (Abdou, 2012: 10). Berbagai literatur manajemen sumber daya manusia menekankan pentingnya "entry point" dalam kontrol kualitas personal di semua bidang (Greives \& Hanafin, 2005, dalam Cameron \& Grootenboer, 2018: 89). Artinya, kualitas masukan yang baik dapat menjadi prediktor bagi performa yang diharapkan. Organization for Economic Co-Operation and Development (OECD) (2005) memberikan panduan mengenai proses rekrutmen, seleksi, dan bagaimana mempekerjakan guru dalam pengembangan kebijakan, antara lain: (1) seleksi guru harus meliputi wawancara, persiapan rencana pembelajaran, dan demonstrasi keterampilan mengajar; (2) memprioritaskan antusiasme, komitmen, dan sensitivitas terhadap kebutuhan anak didik dibandingkan senioritas; (3) calon guru perlu menjalani masa percobaan selama satu atau dua tahun sebelum dapat diangkat; (4) memberikan lingkungan sekolah yang stabil dan penuh dukungan bagi calon guru; (5) memperhatikan bahwa lamanya waktu pengabdian akan memengaruhi insentif yang diterima agar guru terus mengulas dan meningkatkan keterampilan profesinya; (6) mempertimbangkan perlunya guru memperbarui sertifikat mengajarnya setiap 5 sampai 7 tahun untuk memastikan kompetensi mereka masih sesuai dengan yang dipersyaratkan; dan (7) memastikan sistem evaluasi.

Sistem seleksi dan rekrutmen guru di sekolah milik pemerintah berbeda dengan di sekolah swasta. Dalam melakukan manajemen sumber daya manusia (SDM) di instansi pemerintah, ada beberapa hal yang perlu diperhatikan (Armstrong, 2008: 61), yaitu: (1) berinvestasi pada orang dengan meningkatkan tingkat modal intelektual; (2) berbasis manajemen kinerja, yaitu mengintegrasikan nilai-nilai yang terkandung dalam strategi SDM ke dalam 
proses manajemen kinerja dan memastikan tinjauan tersebut; (3) berkonsentrasi pada seberapa baik orang melakukan nilai-nilai itu; (4) berangkat dari desain pekerjaan, yang merupakan komponen kunci yang berkaitan dengan bagaimana pekerjaan dirancang dan bagaimana mereka berhubungan dengan keseluruhan bisnis; dan (5) sistem penghargaan. Dalam mengembangkan strategi penghargaan perlu mempertimbangkan bahwa organisasi pemerintahan adalah bisnis yang digerakkan dengan kerja keras.

Saat ini pengelolaan guru masih berpegang pada UUGD. Dalam UUGD, status dosen dibagi atas dosen tetap dan dosen tidak tetap. Sebaliknya, tidak ada penjelasan mengenai status guru. Padahal di lapangan terdapat beberapa jenis guru berdasarkan statusnya, di antaranya adalah: (1) guru PNS, yakni guru yang diangkat melalui sistem rekrutmen secara terbuka melalui seleksi CPNS guru di mana baik dari sisi kesejahteraan maupun kesempatan dalam peningkatan kapasitas dan pengembangan karir dijamin oleh pemerintah; (2) Guru Tidak Tetap (GTT) yang disebut juga guru honorer atau Guru Bukan PNS (GBPNS), yakni guru di instansi pemerintah maupun swasta yang gajinya dibayarkan oleh APBN atau APBD; dan (3) Guru Tetap Yayasan (GTY), yakni tenaga pendidik di sekolah swasta atau milik yayasan yang berstatus permanen dan digaji oleh sekolahnya serta dapat memperoleh tambahan tunjangan sertifikasi guru dari pemerintah jika memiliki sertifikat pendidik.

Terdapat tiga jenis guru honorer yang bekerja di sekolah milik pemerintah (sekolah negeri) atau guru pemerintah, yaitu: kategori I (K1), kategori II (K2), dan honorer non-kategori (Non-K). Kebijakan rekrutmen guru honorer di sekolah milik pemerintah didorong kebutuhan mendesak untuk mengisi posisi guru yang tidak kunjung dipenuhi pemerintah. Menurut Peraturan Pemerintah Nomor 48 Tahun 2005 jo Peraturan Pemerintah Nomor 43
Tahun 2007, pemda tidak diperbolehkan mengangkat guru tetap non-PNS. Kondisi ini memaksa perekrutan diserahkan kepada masing-masing sekolah agar pembelajaran tetap berlangsung. Prosedur rekrutmen yang dilakukan sekolah tidak diatur. Hal ini menyebabkan beragamnya kualifikasi dan kompetensi guru yang tidak jarang jauh dari standar guru yang ditetapkan dalam UUGD.

Perekrutan guru honorer juga didukung oleh beberapa situasi. Pertama, adanya insentif fiskal kepada pemda. Kedua, Bantuan Operasional Sekolah (BOS) dapat digunakan untuk menggaji guru honorer. Ketiga, adanya peran politik praktis di mana banyak pengangkatan guru honorer terjadi setelah pemilihan kepala daerah. Membagikan pekerjaan mengajar sebagai hadiah politik menjadi lebih umum sekarang setelah bupati dipilih secara langsung, karena mereka memiliki kendali atas departemen pendidikan setempat (Chang et al., 2013: 173 dalam ADB, 2021).

\section{Seleksi dan Rekrutmen Guru di Indonesia dan Perbandingan di Beberapa Negara Lain}

Seleksi guru adalah bagian penting yang melibatkan campur tangan negara. Di Indonesia, sebelum ada UUGD, Iulusan perguruan tinggi yang bukan berasal dari program pendidikan keguruan dapat menjadi guru jika memiliki Akta Mengajar (Akta IV). Kebijakan ini membuka peluang bagi semua lulusan perguruan tinggi untuk menjadi guru. Program ini disebutkan dalam Keputusan Menteri Pendidikan dan Kebudayaan Republik Indonesia Nomor 0211/U/1982 tentang Program Pendidikan Tinggi dalam Lingkungan Departemen Pendidikan dan Kebudayaan. Tujuan Program Akta adalah memberikan kewenangan mengajar atau kewenangan mengajar tambahan yang lebih tinggi melalui pembentukan kompetensi profesional yang diperlukan. Berbekal akta tersebut seorang calon guru dapat mengikuti prosedur penerimaan CPNS. 
Dengan adanya UUGD, dimulai era baru sertifikasi guru yang dijadikan pengakuan kompetensi guru sekaligus menggandakan jumlah pendapatan yang diterima (Revina, Pramana, Fillaili, \& Suryadarma, 2020: 7). Persyaratan Akta IV diganti dengan Sertifikat Pendidik yang diperoleh melalui Pendidikan Profesi Guru (PPG). Meskipun begitu, baru bulan Desember 2013 Kemendikbud menegaskan penghentian berlakunya Akta IV. Dalam Permendikbud Nomor 87 Tahun 2013 tentang Pendidikan Profesi Guru Prajabatan disebutkan juga bahwa sarjana lulusan Fakultas Keguruan dan IImu Pendidikan (FKIP) tidak secara otomatis memperoleh Akta IV. Setelah lulus mereka hanya mendapatkan ijazah saja dengan gelar Sarjana Pendidikan (S.Pd.). Meskipun begitu, implementasi sertifikasi pendidik sebagai syarat seleksi dan rekrutmen calon guru baru diimplementasikan setelah Permendikbud Nomor 87 Tahun 2013. Akibatnya, tidak semua sarjana kependidikan dapat langsung melamar mengikuti tes penerimaan CPNS untuk guru. Mereka harus menambah masa studi dengan mengikuti Program Pendidikan Guru (PPG).

Berbeda dengan Indonesia, di Malaysia rekrutmen guru menggunakan metode internal, yaitu membina calon guru di institusi keguruan agar dapat memastikan pondasi pendidikan. Tujuannya adalah untuk menghasilkan guru-guru bergelar Sarjana Mengajar sehingga hanya guru berkualifikasi yang akan mengisi lowongan guru di sekolah menengah dan dasar. Program ini diluncurkan dalam kerangka konseptual kurikulum pendidikan guru Malaysia. Rekrutmen internal memberikan motivasi yang lebih baik bagi para karyawan. Kemampuan mereka dipertimbangkan dan mereka mendapatkan peluang ditawarkan untuk promosi. Institusi sering kali dapat memanfaatkan kemampuannya dengan lebih baik dalam pekerjaan yang berbeda. Ini lebih dapat diandalkan daripada rekrutmen eksternal karena karyawan yang tersedia saat ini lebih dikenal dari- pada kandidat eksternal (bin Syed Husain, 2020b: 52).

Jepang menggunakan sistem terbuka (open system) yang memberikan kesempatan bagi siapa saja yang telah menamatkan 4 tahun pendidikan untuk menjadi guru. Lulusan 4 tahun pendidikan yang disyaratkan undang-undang diberikan izin mengajar dari dewan pendidikan prefektur (Yamasaki, 2016). Berbeda dengan di Indonesia, di Jepang para mahasiswa mencari pekerjaan ketika masih di tahun terakhir kuliahnya. Rekrutmen guru menggunakan dua tahapan tes (Numano, 2010) yaitu: pertama, tes tertulis meliputi bidang pengajaran, misalnya pedagogi dan hukum serta peraturan pendidikan, tes tertulis mengenai pendidikan secara umum, esai pendek, dan tes bakat. Jika lolos, peserta dapat melanjutkan pada tes berikutnya. Kedua, tes yang meliputi microteaching, tes praktik, wawancara, dan tes tertulis. Kandidat guru yang diterima akan mendapatkan pemberitahuan penerimaan kerja dan diberikan penugasan.

Rekrutmen guru di Tiongkok resmi dilakukan oleh pemerintah. Meskipun dalam pelaksanaannya, pemerintah banyak memberikan otonomi kepada setiap sekolah. Akan tetapi, beberapa hal utama seperti masalah kualifikasi dan masalah gaji masih ditangani secara langsung oleh pemerintah pusat. Bagi rakyat Tiongkok yang memiliki keinginan dan niat luhur untuk menjadi seorang guru, bisa mendaftar dengan syarat memenuhi batas usia yang ditentukan serta kualifikasi lainnya, seperti yang tertulis di Teacher's Law. Menurut Teacher's Law, untuk memperoleh kualifikasi sebagai seorang guru, setiap warga yang tidak memiliki catatan resmi untuk kualifikasi guru sebagaimana diatur dalam undang-undang tersebut, harus mengikuti ujian kualifikasi guru untuk memperoleh kualifikasi resmi. Sistem ujian kualifikasi guru nasional ditentukan oleh Dewan Negara (Badan Keahlian DPR RI, 2019). 


\section{Rekrutmen Guru PPPK}

PPPK sebagaimana dijelaskan dalam Pasal 1 angka 4 Undang-Undang Nomor 5 Tahun 2014 tentang Aparatur Sipil Negara (UU ASN) dan Pasal 1 angka 4 Peraturan Pemerintah Nomor 49 Tahun 2018 tentang Manajemen Pegawai Pemerintah dengan Perjanjian Kerja (PP 49/2018) adalah warga negara Indonesia yang memenuhi syarat tertentu, yang diangkat berdasarkan perjanjian kerja untuk jangka waktu tertentu dalam rangka melaksanakan tugas pemerintahan. PPPK merupakan Aparatur Sipil Negara (ASN). Jabatan yang dapat diisi dengan PPPK adalah: (1) jabatan yang mensyaratkan kompetensi keahlian dan keterampilan tertentu; atau (2) jabatan yang kompetensinya tidak tersedia atau terbatas di kalangan PNS dan diperlukan untuk peningkatan kapasitas organisasi.

Untuk mengatur manajemen PPPK telah diterbitkan Peraturan Presiden (Perpres) Nomor 38 Tahun 2020 tentang Jenis Jabatan yang Dapat Diisi oleh Pegawai Pemerintah dengan Perjanjian Kerja. Pegawai PPPK dapat terdiri dari Jabatan Fungsional (JF) maupun Jabatan Pimpinan Tinggi (JPT). Profesi guru termasuk dalam 147 jabatan yang dapat diisi oleh PPPK. Guru berstatus PPPK baru mulai direkrut pada tahun 2019 ketika Kemendikbud bersepakat dengan Komisi $X$ untuk mengangkat 250.000 guru honorer sebagai PPPK. Seleksi tahun 2019 tersebut menyatakan 34.954 guru honorer K2 telah lulus dan dapat diangkat menjadi guru PPPK. Meskipun begitu, hingga November 2020, Pemerintah belum juga mengeluarkan Surat Keputusan Penempatan (Kamil, 2020). Keterlambatan tersebut menurut PIt. Deputi Bidang SDM Aparatur Kementerian Pendayagunaan Aparatur Negara dan Reformasi Birokrasi (KemenPAN RB), Teguh Widjinarko, disebabkan belum tersedianya formasi dan kelengkapan dokumen menjadi kendala pengangkatan PPPK. Hingga masih ada 12 instansi daerah dan satu instansi pemerintah pusat yang belum ditetapkan karena menunggu kelengkapan dokumen (Kamil, 2020).

Rekrutmen guru PPPK menjadi salah satu sasaran program prioritas Merdeka Belajar di tahun 2021. Rekrutmen ini akan dilaksanakan oleh 548 pemda (Ihsan, 2021). Pembukaan seleksi guru PPPK adalah upaya menyediakan kesempatan yang adil untuk guru-guru honorer yang kompeten agar mendapatkan penghasilan yang layak (Makarim, 2020). Namun, lowongan ini tidak terbatas hanya bagi guru honorer (baik di sekolah negeri maupun swasta). Lulusan PPG yang saat ini tidak/belum mengajar dapat mendaftar dan mengikuti seleksi. Menteri Keuangan (Menkeu) mendukung rencana rekrutmen PPPK yang dapat mengurangi atau mengalihkan status 1,6 juta orang guru non-PNS menjadi guru yang mendapatkan kesejahteraan lebih baik (Indrawati, 2020). Selain itu, Kepala BKN menilai skema PPPK bagi guru ini akan mempermudah manajemen guru dan dapat secara signifikan meningkatkan output kualitas pelayanan pendidikan (BKN, 2021).

Seleksi guru PPPK didasarkan pada Peraturan Menteri PANRB Nomor 72 Tahun 2020 tentang Perubahan Atas Peraturan Menteri PANRB Nomor 2 Tahun 2019 tentang Pengadaan Pegawai Pemerintah dengan Perjanjian Kerja untuk Guru, Dosen, Tenaga Kesehatan, dan Penyuluh Pertanian. Dalam rencana pelaksanaannya, seleksi PPPK 2021 terdapat beberapa perbaikan dibandingkan dengan seleksi tahun 2019. Pertama, peserta seleksi memiliki tiga kali kesempatan. Peserta yang gagal pada seleksi pertama bisa mencoba lagi sampai tiga kali seleksi, baik pada 2021 maupun tahun berikutnya. Kedua, pemerintah menyediakan materi persiapan seleksi secara daring agar semua calon peserta seleksi dapat mengakses untuk digunakan sebagai bahan pelatihan mandiri. Ketiga, anggaran PPPK berasal dari pemerintah pusat. Hal ini berbeda dengan seleksi-seleksi sebelumnya, di mana pemda harus memper- 
siapkan anggaran gaji peserta yang lulus seleksi guru PPPK. Keempat, biaya penye- lenggaraan seleksi PPPK juga ditanggung pemerintah pusat (Arifa, 2020).

\begin{tabular}{|c|c|}
\hline Pendaftaran & $\begin{array}{l}\text { - Pendaftar memilih satu dari tiga kategori (Guru Honorer/Individu baru yang } \\
\text { telah memiliki sertifikat pendidik/Guru Honorer K2). } \\
\text { - } \\
\text { Pendaftar menginput ID berupa Nomor Registrasi K2/NUPTK/NIK/Nomor } \\
\text { Sertifikat Pendidik. }\end{array}$ \\
\hline $\begin{array}{c}\text { Seleksi } \\
\text { Administrasi }\end{array}$ & $\begin{array}{l}\text { - Seleksi berkas berupa: Pernyataan tanggung jawab mutlak, KTP, dan Surat } \\
\text { Lamaran. } \\
\text { - } \quad \text { Pengecekan linieritas mata pelajaran dengan sertifikat pendidik atau latar } \\
\text { belakang pendidikan (by system). } \\
\text { - } \quad \text { Pengecekan nomor mahasiswa terkait ijazah dan jurusan (by system). }\end{array}$ \\
\hline Asesmen & $\begin{array}{l}\text { - Tiga konten asesmen: Kompetensi teknis; Manajerial dan sosio-kultural, dan } \\
\text { Pertanyaan wawancara yang dijawab tertulis. } \\
\text { - } \quad \text { Peserta diberi kesempatan mengikuti ujian seleksi hingga tiga kali. }\end{array}$ \\
\hline Pengumuman & $\begin{array}{l}\text { - } \quad \text { Panselnas menerima hasil asesmen. } \\
\text { - } \quad \text { BKN melakukan perangkingan peserta sesuai formasi per kabupaten/kota. } \\
\text { - } \quad \text { Panselnas menyerahkan hasil perangkingan peserta sesuai formasi ke pemda. } \\
\text { - } \quad \text { Pemda mengumumkan peserta yang luus beserta sekolah penempatan. }\end{array}$ \\
\hline Pemberkasan & $\begin{array}{l}\text { - } \quad \text { Pemda membuat SK Pengangkatan serta kontrak. } \\
\text { - } \quad \text { Pemda menyerahkan SK Pengangkatan serta kontrak. }\end{array}$ \\
\hline
\end{tabular}

\section{Bagan 2. \\ Tahapan Pengadaan Guru ASN PPPK 2021}

Sumber: Kemendikbud (18 Januari 2021)

\section{Pro Kontra Seleksi Guru dengan Sistem PPPK}

Seleksi guru dengan sistem PPPK membuka peluang bagi guru yang sudah mengajar untuk mengikuti seleksi tanpa terikat batasan usia seperti yang ditetapkan dalam seleksi CPNS. Artinya, guru yang berusia lebih dari 35 tahun berkesempatan menjadi ASN jika lolos tes. Data Kemendikbud memang menunjukkan banyaknya jumlah guru honorer yang berusia di atas 35 tahun (lihat Bagan 3). Namun demikian, untuk menjaring guru yang berkualitas tidak serta-merta semua guru honorer diangkat sebagai PPPK. Mereka tetap harus memenuhi persyaratan yang ditetapkan serta mengikuti seluruh proses dan lolos seleksi (Arifa, 2020: 15). Dibukanya seleksi PPPK bagi lulusan PPG yang belum mengajar juga menambah persaingan bagi guru honorer.

Pelaksanaan seleksi dan rekrutmen melalui sistem PPPK menyisakan beberapa potensi permasalahan. Pertama, masih ada pemda yang belum mengaju- kan usulan sesuai dengan kebutuhan guru di daerahnya, karena masih ada keraguan sumber anggaran yang akan digunakan untuk menggaji PPPK nantinya. Mendikbud sudah berkali-kali meyakinkan bahwa anggaran seleksi dan gaji akan disediakan pemerintah pusat. Dalam paparannya pada 30 Maret 2021, Kemendikbud mengumumkan total usulan formasi pemerintah daerah berjumlah 523.120. Dengan kondisi 27 daerah tidak mengajukan formasi PPPK, 8 di antaranya berada di Papua dan Papua Barat, serta 165 daerah mengusulkan kurang dari $50 \%$ dari formasi yang dibutuhkan (Pramestuti, 2021).

Kedua, Kemendikbud perlu bekerja sama dengan pihak terkait dalam menyusun formasi guru PPPK sesuai kebutuhan daerah dan disinkronkan dengan jumlah kekurangan guru pada Dapodik. Selama ini, pengadaan guru disesuaikan dengan program penerimaan CPNS secara nasional. Terkait hal ini, masih terdapat ketidaktepatan penempatan guru PPPK hasil rekrutmen tahun 2019 di beberapa daerah. Contohnya, penempatan PPPK guru olah- 


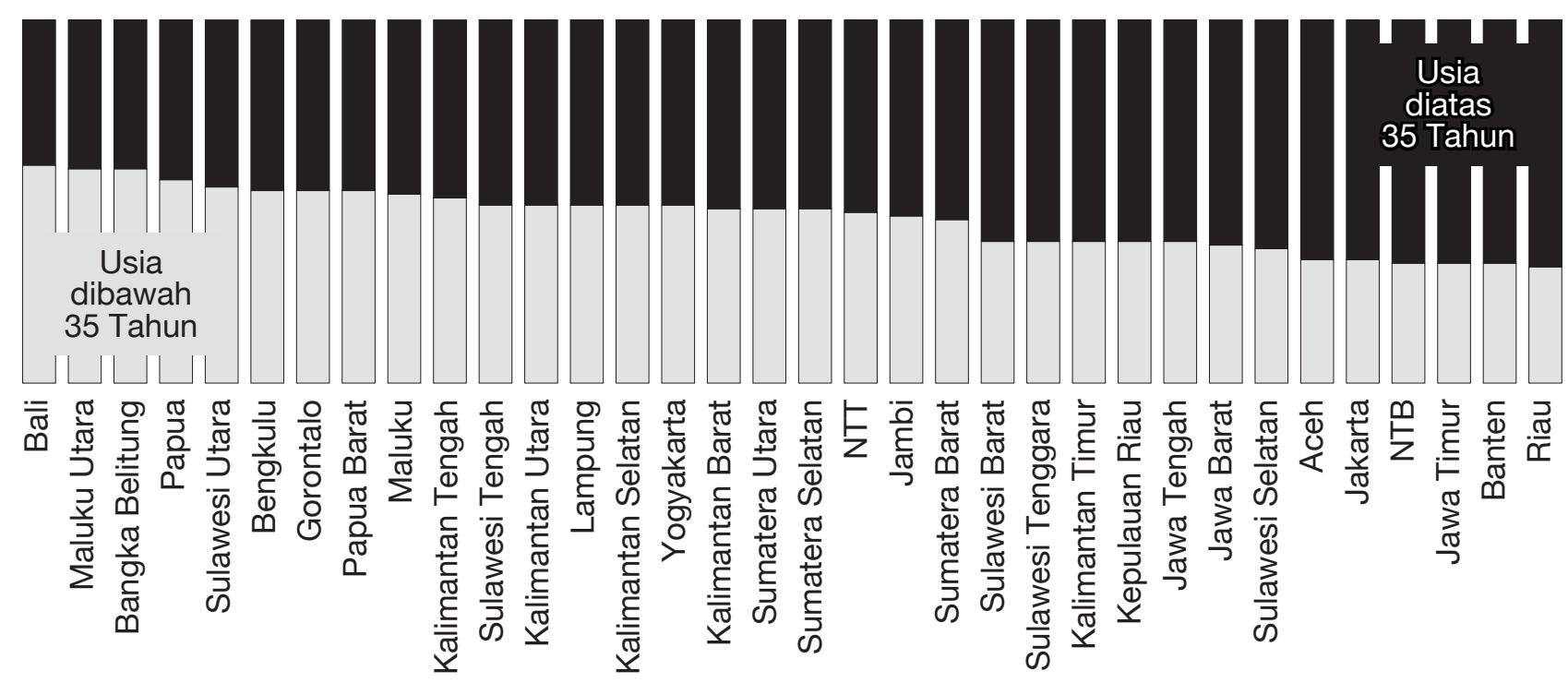

Bagan 3.

Guru Bukan PNS di Sekolah Negeri

Sumber: Paparan Sesditjen Guru dan Tenaga Kependidikan (GTK), Kementerian Pendidikan dan Kebudayaan (Kemendikbud), Nunuk Suryani pada RDP dengan Komisi X (18 Januari 2021)

raga di SD Negeri 1 Beran dan SD Negeri 1 Pulosaren Kecamatan Kepil Kabupaten Wonosobo. Penempatan guru di dua sekolah tersebut menjadikan sekolah kelebihan guru, akibatnya guru PNS di sekolah tersebut kekurangan jam mengajar sehingga harus dimutasi ke sekolah lain yang kekurangan guru tetapi justru tidak ada penempatan guru PPPK di sekolah tersebut (Supriyatin, 2021). Hal ini disebabkan karena belum sinkronnya data guru pada Dapodik dan kondisi riil di daerah. Ketiga, berkaitan dengan penyelenggaraan, perlu adanya jaminan bahwa pelaksanaan seleksi PPPK dilakukan secara profesional dan akuntabel. Penyelenggaraan seleksi PPPK diharapkan menghasilkan guru yang berkompeten dan profesional tanpa adanya celah yang berpotensi menimbulkan kecurangan dalam seluruh rangkaian tahapan penyelenggaraan.

\section{PPPK Solusi Permasalahan Guru?}

\section{Perbaikan Tata Kelola Guru}

Tata kelola guru adalah sebuah sistem yang komprehensif yang mengelola semua aspek dalam manajemen sumber daya manusia guru. Berkaitan dengan pembenahan tata kelola guru, pemerintah mengajukan beberapa poin sebagai pertim-
Tabel 1.

Pro dan Kontra

Pelaksanaan Seleksi Guru PPPK

\begin{tabular}{|c|c|}
\hline Pro & Kontra \\
\hline $\begin{array}{l}\text { Memberikan } \\
\text { kesempatan kepada } \\
\text { siapa saja untuk } \\
\text { melamar menjadi } \\
\text { guru sebagai } \\
\text { pegawai pemerintah } \\
\text { tanpa batasan usia } \\
\text { sebagaimana yang } \\
\text { diberlakukan dalam } \\
\text { penerimaan CPNS. }\end{array}$ & $\begin{array}{l}\text { Guru honorer yang } \\
\text { sudah lama mengabdi } \\
\text { kurang diprioritaskan } \\
\text { dan dianggap tidak } \\
\text { dihargai masa } \\
\text { pengabdiannya. }\end{array}$ \\
\hline $\begin{array}{l}\text { Efisiensi anggaran } \\
\text { negara. }\end{array}$ & $\begin{array}{l}\text { PPPK tidak diberikan } \\
\text { pensiun seperti PNS. }\end{array}$ \\
\hline $\begin{array}{l}\text { Mengisi formasi } \\
\text { yang kosong sesuai } \\
\text { kebutuhan daerah. }\end{array}$ & $\begin{array}{l}\text { Persaingan yang ketat } \\
\text { bukan saja dengan } \\
\text { sesama honorer diatas } \\
35 \text { tahun, tapi juga } \\
\text { dengan lulusan PPG } \\
\text { yang tidak mengajar. }\end{array}$ \\
\hline $\begin{array}{l}\text { PPPK memperoleh } \\
\text { jaminan kesejahteraan } \\
\text { dan kesempatan } \\
\text { pengembangan karir } \\
\text { dari pemerintah. }\end{array}$ & $\begin{array}{l}\text { PPPK tidak bisa } \\
\text { menjadi PNS. }\end{array}$ \\
\hline
\end{tabular}

Formasi guru PPPK sesuai kebutuhan daerah dan Ada celah untuk KKN, misalnya dengan titipmenitip calon.

disinkronkan dengan

jumlah kekurangan

guru pada Dapodik. 
bangan pengadaan guru PPPK. Pertama, adanya kesenjangan antara ketersediaan dan kebutuhan guru. Kebijakan pemerintah untuk melakukan moratorium penerimaan guru PNS telah membuka lubang yang sangat besar dalam upaya pemenuh-an kebutuhan guru. Kebijakan BKN mengenai perlunya perubahan pola seleksi dan rekrutmen guru disebabkan masih kurangnya jumlah guru yang mengabdi. Pada tanggal 24 Agustus 2011 dikeluarkan Peraturan Bersama tentang Penundaan Sementara Penerimaan CPNS oleh MenPANRB, Menteri Dalam Negeri (Mendagri), dan Menteri Keuangan (Menkeu) untuk menutup penambahan pegawai pemerintah dan lebih fokus membangun infrastruktur. Moratorium penerimaan CPNS telah ditetapkan sebanyak dua kali. Dimulai pada Pemerintahan SBY-JK yang berlangsung dari 1 September 2011 sampai 31 Desember 2012 (Darmaningtyas, 2014: 18). Kemudian, dilanjutkan selama pemerintahan Joko Widodo sejak tahun 2015.

Sebenarnya kebijakan moratorium tidak berlaku untuk tenaga profesi guru dan tenaga medis, karena jumlahnya masih kurang (Darmaningtyas, 2014: 18). Meskipun demikian, tidak semua daerah memanfaatkan pengecualian tersebut. Akibatnya kekurangan guru harus ditanggung masing-masing sekolah dengan merekrut tenaga honorer. Mereka berharap status honorer dapat menjadi batu loncatan agar dapat diangkat menjadi PNS. Harapan ini tumbuh karena pemerintahan SBY pernah mengangkat guru honorer menjadi PNS tanpa tes sehingga dipandang sebagai sebuah jenjang karir bagi guru honorer. Padahal, banyak guru honorer yang tidak memenuhi kualifikasi yang ditetapkan dalam UUGD, misalnya berpendidikan S-1.

Di sisi lain, saat ini terdapat permasalahan ketidaksinkronan antara proses penyiapan calon guru (yang dilakukan di Lembaga Pendidikan Tenaga Kependidikan (LPTK) dengan kebutuhan di lapangan terlihat jelas dalam proses seleksi dan rekrutmen guru. Perencanaan pemerintah tidak memperhatikan perbandingan antara jumlah lulusan LPTK yang telah mengikuti PPG dengan formasi guru. Jumlah LPTK semakin bertambah karena besarnya animo masyarakat ingin jadi guru, namun tidak semua lulusan dapat tertampung di sekolah. Ini berbeda dengan di Malaysia yang merencanakan jumlah calon guru yang dididik sesuai dengan proyeksi kebutuhan guru. Sementara di Tiongkok dan Jepang, proses pendidikan guru menjadi pondasi yang penting dalam perencanaan pembangunan pendidikan.

Hasil penelitian Balitbang Depdikbud pada tahun 1995 menyatakan seringnya IKIP disorot sebagai lembaga tinggi yang terisolasi dari kepentingan pembangunan pendidikan secara makro (Abbas, 2020). Kondisi ini tampak terus-menerus berlangsung hingga saat ini. LPTK terus bertambah, yang artinya lulusan juga semakin banyak yang jumlahnya melebihi kebutuhan guru setiap tahun. Buktinya pada tahun 2019 Mendikbud Muhadjir Effendy mengakui ketidakseimbangan suplai dan permintaan tenaga guru, yang terlihat dari angka 350 ribu guru lulusan LPTK setiap tahun, tidak dapat diserap karena kebutuhan guru maksimal 150 ribu. Berarti ada kelebihan 200 ribu guru setiap tahunnya (Potret Pendidikan, 2019).

Kedua, distribusi guru tidak merata. Perhimpunan untuk Pendidikan dan Guru (P2G) menilai jumlah guru secara ratarata sebenarnya sebanding dengan jumlah siswa. Namun, distribusi guru tidak merata sehingga ada sekolah di suatu daerah yang memiliki cukup, bahkan kelebihan guru PNS. Sementara itu, masih banyak sekolah di daerah lainnya kekurangan guru PNS. Misalnya, di SMK Negeri 7 Ende Moni, Kelimutu, Nusa Tenggara Timur seluruh tenaga pendidiknya adalah guru honorer kecuali kepala sekolah (Arifa, 2020). Namun demikian, perlu dicermati bahwa penyebaran guru tidak sekadar dari jumlahnya tetapi juga perlu memperhatikan mata pelajaran yang diampu. Meskipun di satu 
daerah terdapat sejumlah guru, tetapi belum tentu memenuhi kebutuhan berdasarkan mata pelajaran dan jenjang pendidikan. Bisa jadi, mereka semua mengajar mata pelajaran yang sama sehingga terjadi kelebihan guru pada mata pelajaran tertentu, tetapi kekurangan guru di mata pelajaran lainnya. Jadi, angka yang digunakan untuk membagi rerata guru di daerah harus dipecah menjadi keunikan mata pelajarannya masing-masing, sebab guru mengajar berdasarkan mata pelajarannya.

Kemendikbud menyatakan bahwa selama ini terjadi ketidakseimbangan sistem distribusi guru antardaerah secara nasional. Pada banyak kasus, guru mudah sekali pindah daerah tugas sehingga daerah yang ditinggalkan kekurangan guru. Hal ini senada dengan pernyataan Kepala BKN, Bima Haria Wibisana, bahwa alasan perekrutan guru melalui PPPK berkaitan dengan persoalan buruknya sistem distribusi guru secara nasional, karena banyak guru yang baru diangkat sebagai PNS meminta pindah lokasi (Maharani, 2020).

Untuk permasalahan mutasi, UUGD memberikan kewenangan kepada pemda untuk memindahtugaskan guru karena alasan kebutuhan satuan pendidikan dan/ atau promosi. Pemindahan guru pada satuan pendidikan yang diselenggarakan oleh masyarakat diatur oleh penyelenggara pendidikan atau satuan pendidikan yang bersangkutan berdasarkan perjanjian kerja atau kesepakatan kerja bersama. UUGD tidak memberikan batasan yang tegas berapa lama seorang guru harus melakukan tugas di tempat yang ditunjuk, akibatnya banyak kasus seorang guru baru minta pindah ketika ditempatkan di daerah yang kurang disukainya (misalnya daerah terdepan, terpencil, dan tertinggal (3T), atau sulit secara geografis, atau jauh dari keluarga). Mutasi memang merupakan hak guru, namun mutasi yang tidak terkendali akan menyebabkan bencana ketika daerah yang ditinggalkan menjadi kekurangan guru. Guru juga rentan berada di bawah kenda- li politik penguasa daerahnya yang dapat dengan mudah memutasi guru tanpa proses yang objektif. Sebaliknya, pengaruh politik juga dapat membuat mutasi guru ke tempat yang tidak membutuhkan tambahan guru. Dari kondisi ini bisa disimpulkan bahwa distribusi guru yang tidak merata karena mudahnya mutasi disebabkan karena lemahnya pengawasan pemerintah terhadap arus perpindahan guru.

Ketiga, kualifikasi dan kompetensi guru masih rendah. Permasalahan kualifikasi guru harus dimulai dari materi baku (raw material) yang diterima sebagai guru. Perbaikan kualitas guru memang sudah mulai dijalankan sejak tahun 2005, meski dengan perkembangan yang lambat. Oleh karena itu, kualifikasi dan kompetensi guru perlu ditinjau dari instansi yang bertugas mempersiapkan guru, yaitu LPTK. LPTK sebagai produsen guru tidak memiliki hubungan langsung dengan sekolah sebagai konsumen. Pada periode pemerintahan Jokowi pertama (2014-2019), kedua instansi tersebut dikelola oleh dua kementerian berbeda. Hal ini menjadi penghambat untuk mensinergikan kebutuhan guru dengan kualitas yang sedang digodok di LPTK. Penelitian Alawiyah (2018: 128) menemukan bahwa kualitas guru yang dihasilkan LPTK tidak sesuai dengan kebutuhan di masyarakat. Akibatnya fungsi LPTK untuk mencetak guru yang kompeten belum dapat dilaksanakan. Sekarang dengan digabungkannya kembali kedua kementerian maka tampaknya ada harapan untuk memperbaiki pola pendidikan dan rekrutmen guru.

Saat ini LPTK hanya bertugas untuk memberikan pendidikan kepada calon guru. Seharusnya LPTK juga menjadi penyaringan awal untuk seleksi guru baru (kredensial) (Rosyidi, 2020). Dengan menyaring calon mahasiswa kependidikan yang sesuai kriteria guru, pemerintah mengurangi biaya untuk setiap lulusan yang tidak cocok menjadi guru. Artinya pemerintah perlu mempersiapkan talent pool di LPTK. Hal ini tentu harus diimbangi 
dengan sistem penerimaan calon mahasiswa yang linier dengan memanfaatkan $\mathrm{Uji}$ Kompetensi sebagai pintu masuk seorang calon guru menjadi guru pemerintah. Di sini pemerintah dapat menetapkan kuota jumlah mahasiswa keguruan yang sesuai dengan perencanaan kebutuhan guru pada waktu mahasiswa lulus (misalnya 5 tahun yang akan datang). Dengan metode ini, pemerintah dapat: (1) mengatur jumlah mahasiswa yang akan dididik kemudian diangkat menjadi guru sehingga menghindari oversupply; dan (2) tidak menambah pengangguran baru dari lulusan LPTK atau lulusan LPTK yang terpaksa menjadi tenaga honorer.

Lemahnya peran LPTK juga disoroti oleh PGRI dengan menuding tidak adanya payung hukum yang jelas. Tidak ada UU yang mengatur bahwa LPTK harus menghasilkan guru yang bersertifikat (Rosyidi, 2020). Malah sarjana kependidikan diberikan kebebasan untuk melanjutkan ke PPG sehingga secara tidak langsung UUGD melepaskan tanggung jawab LPTK untuk menghasilkan calon guru. Padahal, pondasi yang ingin dibangun adalah menguatkan LPTK sebagai lembaga pencetak calon guru. Sebaiknya pendidikan di LPTK dilaksanakan secara berkelanjutan mulai dari S-1 sampai PPG sehingga semua lulusan siap menjadi guru.

\section{Penyelesaian Isu Guru Honorer}

Menurut perhitungan Kemendikbud, jumlah guru yang seharusnya bekerja di sekolah negeri adalah sebanyak 2,2 juta guru. Sementara saat ini baru terdapat 1,1 juta guru PNS dan 742 ribu guru honorer. Jumlah guru honorer lebih dari setengah jumlah guru PNS, yang artinya setidaknya sejumlah itulah kekurangan guru di sekolah-sekolah milik pemerintah. Dari keseluruhan guru honorer tersebut belum semuanya terpetakan kualifikasi dan kompetensinya. Hal ini jelas merupakan kegagalan dari pihak pemerintah untuk memenuhi layanan pendidikan yang sesuai dengan standar.

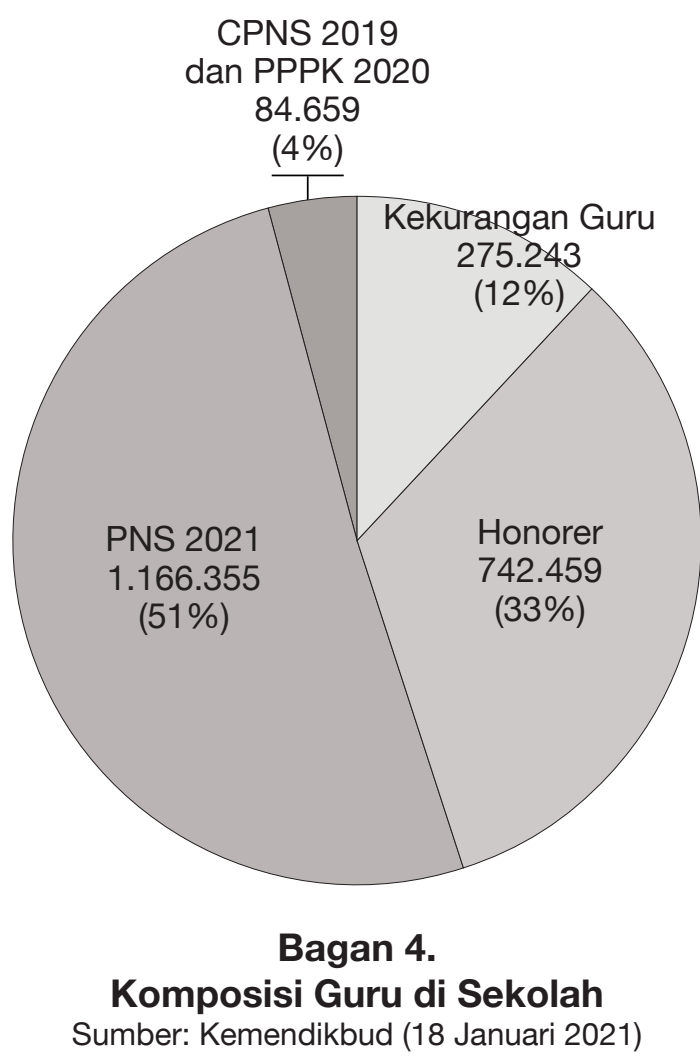

Jika hanya ingin mengisi formasi, maka Kemendikbud tinggal mengangkat semua guru honorer dan membuka lowongan baru untuk menambah kekurangan. Namun, meski 742 ribu guru honorer di sekolah negeri diangkat seluruhnya menjadi guru PPPK, masih terdapat kekurangan guru di sekolah negeri sebanyak 275 ribu. Selain itu masih ada guru honorer yang belum berkualifikasi pendidikan S-1 sebagaimana disyaratkan dalam UUGD. Untuk itu, Kemendikbud juga membuka kesempatan bagi lulusan PPG yang tidak mengajar. Kondisi ini yang menjadi kendala bagi sebagian besar honorer yang telah lama mengabdi. Honorer yang sudah tua merasa tidak sanggup bersaing dengan calon guru muda yang masih segar sehingga menimbulkan kekhawatiran akan tidak lolos tes.

Oleh karena itu, guru honorer berharap presiden dapat mengeluarkan Keppres untuk mengangkat tenaga honorer (terutama nonkategori) sebagai PNS tanpa melalui tes. Anggota DPR RI dari Komisi II, Guspardi, mengingatkan bahwa pemerintah pernah menjanjikan tenaga honorer diangkat sebagai ASN secara otomatis. 
Namun, ternyata ini tidak terlaksana karena kenyataanya masih harus melalui seleksi ("Komisi II Berkeinginan", 2021). Sebelumnya sebagai bentuk pemenuhan janji politiknya, pemerintahan SBY-JK mengeluarkan Peraturan Pemerintah Nomor 48 Tahun 2005 tentang Pengangkatan Tenaga Honorer menjadi CPNS (PP 48/2005). Pengangkatan ini didasarkan pada bahwa tenaga honorer yang telah lama bekerja dan atau tenaganya sangat dibutuhkan oleh pemerintah dan memenuhi syarat yang ditentukan dalam PP ini, dapat diangkat menjadi CPNS. PP 48/2005 jelas-jelas menyebutkan bahwa pengangkatan tenaga honorer menjadi CPNS diprioritaskan bagi yang melaksanakan tugas sebagai: (1) tenaga guru; (2) tenaga kesehatan pada unit pelayanan kesehatan; (3) tenaga penyuluh di bidang pertanian, perikanan, peternakan; dan (4) tenaga teknis lainnya yang sangat dibutuhkan pemerintah.

PP tersebut juga menjelaskan ketentuan usia, yaitu minimal 35 tahun dengan masa kerja satu sampai kurang dari lima tahun secara terus-menerus. Tenaga honorer tertua yang dapat diangkat adalah yang berusia maksimal 46 tahun dengan masa kerja 20 tahun secara terus-menerus. Proses pengangkatan harus dilalui dengan seleksi administrasi disiplin, integritas, kesehatan, dan kompetensi. Pengangkatan ini juga memegang prinsip mengutamakan calon yang berusia lebih tua.

Ketentuan masa kerja minimal ini diubah dengan Peraturan Pemerintah Nomor 43 Tahun 2007 tentang Perubahan Atas Peraturan Pemerintah Nomor 48 Tahun 2005 Tentang Pengangkatan Tenaga Honorer Menjadi CPNS (PP 43/2007), yang menyatakan batas usia maksimal tetap 46 tahun tapi dengan masa kerja 19 tahun. Kemudian tidak ada batas usia minimal lagi, hanya masa kerja minimal 1 tahun. Namun, dalam perjalanannya setelah dilakukan evaluasi sampai dengan Tahun Anggaran 2009 masih terdapat tenaga honorer yang memenuhi syarat PP $48 / 2005$ sebagaimana telah diubah dengan
PP 43/2007, tetapi belum diangkat sebagai CPNS. Janji politik ini tidak lagi bisa diimplementasikan ketika pemerintah mengeluarkan UU ASN, karena menutup kesempatan tenaga honorer di atas 35 tahun untuk menjadi PNS.

Untuk menjawab kekhawatiran guru honorer mengenai ketatnya persaingan dalam seleksi PPPK, Kemendikbud telah menyiapkan program pembekalan yang dapat membantu peserta seleksi, seperti dapat dilihat di Bagan 5. Diharapkan dengan adanya program tersebut dapat memberikan tambahan pengetahuan dan kesiapan mental bagi peserta tes PPPK untuk menghadapi tes.

Sebagaimana telah disebutkan di atas, banyak guru honorer yang direkrut tanpa memperhatikan kualifikasinya. Maka akan ada kemungkinan guru honorer yang tidak lolos seleksi PPPK. Oleh karena itu, PPPK tidak akan menyelesaikan permasalahan honorer secara tuntas. Malah, pemerintah dituntut untuk menyiapkan strategi baru untuk menyelesaikan sisa guru honorer yang tidak lolos seleksi PPPK. Yang berarti guru-guru dengan penghargaan rendah akan terus dilestarikan.

Pemerintah pun dihadapkan dengan tuntutan strategi baru bagaimana mengelola "pahlawan pendidikan" tersebut. Jika pemerintah memilih untuk memutuskan hubungan kerja dengan para honorer yang tidak lolos PPPK, maka: (1) sekolah akan kekurangan guru; (2) pemerintah tidak adil kepada mereka yang telah membantu proses pembelajaran; dan (3) sekolah yang kekurangan guru akan terus merekrut guru honorer dengan upah minim.

Sebaiknya Kemendikbud mengadopsi sistem rekognisi pembelajaran lampau (RPL) yang digunakan Kemenristekdikti. RPL adalah proses pengakuan atas capaian pembelajaran seseorang yang baik melalui pendidikan formal, nonformal, informal, atau otodidak melalui pengalaman hidupnya. Pengakuan ini dimaksudkan untuk menempatkan seseorang pada jenjang kualifikasi Kerangka Kualifikasi 


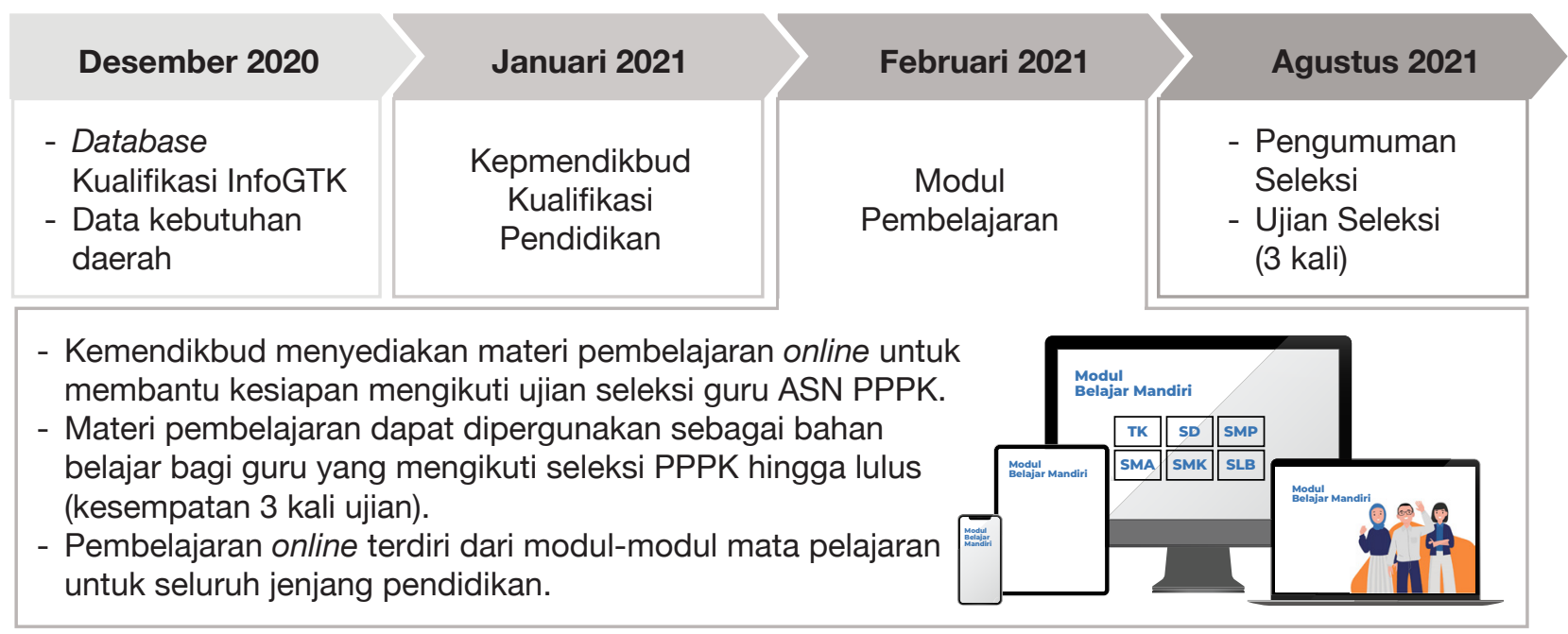

\section{Bagan 5.}

\section{Perkembangan Persiapan Rekrutmen Guru ASN PPPK}

Sumber: Kemendikbud (18 Januari 2021)

Nasional Indonesia (KKNI). Dengan merujuk pada jenjang kualifikasinya, pemerintah dapat menyesuaikan penghargaan yang sepadan.

Selain itu, untuk meningkatkan efektivitas penyaringan, tes seleksi harus bervariasi tidak terbatas pada tes tertulis (paper and pencil test). Pemerintah dapat memilih beberapa metode asesmen yang disarankan Hobson et al. (2010: 12) yaitu: (1) pemeriksaan (examination), untuk mengukur pengetahuan dan keterampilan. Pemeriksaan ini dapat dilakukan dengan tes tertulis (paper and pencil test) maupun tes lisan (oral and written test); (2) observasi praktik berbasis kelas dan sekolah, dengan kata lain praktik mengajar; (3) wawancara, sering kali digunakan bersamaan dengan metode lain; (4) portfolio-alat untuk mengumpulkan dokumen dan artefak pengajaran yang terorganisir-dapat digunakan untuk mengetahui kemajuan kinerja dan menjadi bukti apakah guru memenuhi standar; dan terakhir (5) penugasan dalam berbagai bentuk (termasuk esai, presentasi tertulis dan lisan, buku harian reflektif, laporan proyek penelitian aksi) yang digunakan di banyak negara untuk menilai pengetahuan, pemahaman, dan keterampilan guru pemula (misalnya refleksi kritis). Adanya ketakutan calon peserta seleksi PPPK perlu diperhatikan karena meskipun bisa dilihat sebagai faktor psikosomatis, namun dapat berdampak pada efektivitas pengukuran. Penggunaan tes yang tepat untuk guru honorer yang sudah senior dapat meningkatkan efektivitas.

\section{Reformasi Birokrasi dengan Peningkatan Kualitas Layanan Publik oleh ASN}

Kemendikbud merujuk pada UU ASN dan Perpres Nomor 81 Tahun 2010 tentang Grand Design Reformasi Birokrasi yang menyatakan perlunya reformasi untuk melakukan perbaikan kualitas pegawai pemerintah (ASN) dan manajemen pegawai secara keseluruhan. Pemerintah meyakini banyak pegawai yang tidak memenuhi syarat menjadikan pelayanan pendidikan belum dapat mencapai targettarget pembangunan yang dicita-citakan. Oleh karena itu, pembenahan manajemen secara keseluruhan adalah hal yang mutlak dengan melakukan perbaikan pengadaan CPNS (seleksi dan rekrutmen yang berdasarkan kebutuhan) dan pembatasan mutasi.

Seleksi dan rekrutmen dilakukan berdasarkan analisis kebutuhan di daerah. Untuk penerimaan PPPK 2021 ini sudah dilakukan permintaan kebutuhan dari pemda agar formasi yang disediakan sesuai dengan kebutuhan. Namun, Kemendikbud juga harus menyamakan permin- 
taan dari daerah disesuaikan dengan data yang dimiliki Kemendikbud. Selain itu, pengadaan harus difokuskan pada calon guru lulusan PPG dan menempatkan LPTK sebagai penyaring awal dalam sistem seleksi dan rekrutmen guru.

Di sisi lain, telah dikeluarkan Peraturan Menteri Dalam Negeri Nomor 58 Tahun 2019 tentang Mutasi Pegawai Negeri Sipil Antarkabupaten/kota Antarprovin$\mathrm{si}$, dan Antarprovinsi. Dalam peraturan tersebut, menekankan peran Kementerian Dalam Negeri (Kemendagri) terhadap pembatasan mutasi tenaga pendidik (Guru) dalam mengelola lalu lintas mutasi. Kemendagri-selaku instansi pembina umum penyelenggaraan urusan pemerintahan daerah-sebelum melakukan penetapan mutasi, dalam memberikan persetujuan mutasi PNS daerah perlu melakukan koordinasi dengan instansi terkait. Salah satu upaya yang dilakukan adalah dengan memberlakukan sistem aplikasi e-mutasi Ditjen Otda Kemendagri dan sistem aplikasi simratio.gtk.kemendikbud.go.id (Bahri, 2021). Sistem e-mutasi merupakan bentuk amanat Peraturan Menteri Dalam Negeri Republik Indonesia Nomor 58 Tahun 2019 yang ditujukan untuk pengendalian dan pemerataan PNS di daerah sebagai bagian manajemen pengembangan karir. Mutasi PNS perlu dilakukan sesuai dengan kualifikasi, kompetensi, dan analisis beban kerja serta kebutuhan organisasi. Akan tetapi, bagaimana implementasi di lapangan masih membutuhkan penelitian lebih lanjut, karena sistem ini hanya memindahkan pola mutasi konvensional ke sistem daring. Salah satu yang menjadi tantangan adalah bagaimana pemda melaksanakan mutasi tanpa dipengaruhi kepentingan politik.

\section{Diskusi}

Komisi X DPR RI (13 Januari 2021) mencatat tiga hal pokok kesejahteraan guru yang berefek pada kualitas pendidikan nasional, yaitu: (1) skema pengangkatan guru yang tidak sesuai dengan kebutuhan sehingga perlu revisi total dari berbagai aspek; (2) pemerataan guru karena banyak guru yang menumpuk di tempat yang tidak perlu; dan (3) kompetensi guru. Dari hasil diskusi dengan para guru dan instansi pemerintah terkait, dapat dipetakan permasalahan seleksi PPPK terhadap tujuan-tujuan Kemendikbud seperti dapat dilihat di Tabel 2.

Persoalan-persoalan yang berkembang di lapangan perlu dijawab dengan peraturan perundang-undangan. UUGD yang menjadi acuan hanya mengatur pola pemenuhan guru yang tercantum dalam Pasal 24, yaitu: mengenai pengangkatan, penempatan, pemindahan, dan pemberhentian. Hal ini mengatur kewajiban pemerintah untuk memenuhi kebutuhan guru sesuai dengan jumlah, kualifikasi, dan kompetensi secara merata. Akan tetapi, peraturan ini tidak menyinggung bagaimana pemerintah memenuhi kebutuhan guru ini. Tidak pula dijelaskan proses seleksi dan rekrutmen yang merupakan tahapan penting untuk menjembatani proses penyiapan guru yang disinggung pada Pasal 10 (pendidikan profesi bertujuan untuk membekali guru dengan kompetensi guru). Bagaimana pelaksanaan teknis seleksi guru pun tidak disinggung dalam Peraturan Pemerintah Nomor 74 Tahun 2008 yang telah direvisi dengan Peraturan Pemerintah Nomor 19 Tahun 2017 tentang Perubahan atas Peraturan Pemerintah Nomor 74 Tahun 2008 tentang Guru. Dari sini kita lihat masih ada ruang untuk menyempurnakan peraturan perundang-undangan tentang guru.

Mengacu pada UUGD, seleksi PPPK merupakan upaya memenuhi kebutuhan guru, baik dalam jumlah, kualifikasi akademik, maupun dalam kompetensi secara merata untuk menjamin keberlangsungan satuan pendidikan yang diselenggarakan oleh pemerintah. Namun demikian, masih perlu terus dibenahi agar dapat semaksimal mungkin menyelesaikan permasalahan berkaitan dengan guru. Melihat rekrutmen di negara lain, Indonesia memiliki kesamaan dengan Malaysia 
Tabel 2.

Peta Permasalahan PPPK

\begin{tabular}{|c|c|c|}
\hline $\begin{array}{c}\text { Tujuan } \\
\text { Rekrutmen PPPK }\end{array}$ & Dampak PPPK & Permasalahan yang Tersisa \\
\hline $\begin{array}{l}\text { Perbaikan tata } \\
\text { kelola guru }\end{array}$ & $\begin{array}{l}\text { Adanya penghitungan kebutuhan } \\
\text { di daerah sebelum dilaksanakan } \\
\text { seleksi dan rekrutmen. }\end{array}$ & $\begin{array}{l}\text { PNS lebih difokuskan pada pembuatan } \\
\text { keputusan (kebijakan), sementara PPPK fokus } \\
\text { pada peningkatan kualitas pelayanan publik } \\
\text { dan mendorong percepatan peningkatan } \\
\text { profesionalisme serta kinerja instansi pemerintah. } \\
\text { Bagaimana pemerintah akan membedakan } \\
\text { tugas kedua status guru tersebut ketika } \\
\text { fungsi utama mereka sama-sama mengajar? } \\
\text { Dengan membedakan tugas di atas, BKN tetap } \\
\text { mempertahankan kastanisasi yang selama ini } \\
\text { tumbuh di dunia pendidikan antara guru PNS } \\
\text { dengan guru non-PNS. }\end{array}$ \\
\hline $\begin{array}{l}\text { Penyelesaian isu } \\
\text { honorer }\end{array}$ & $\begin{array}{l}\text { Memberikan kesempatan pada } \\
\text { honorer yang berusia diatas } 35 \\
\text { tahun untuk ikut seleksi. }\end{array}$ & $\begin{array}{l}\text { Akan ada guru honorer yang tidak memenuhi } \\
\text { syarat, maka akan tetap menjadi permasalahan. }\end{array}$ \\
\hline $\begin{array}{l}\text { Reformasi } \\
\text { birokrasi }\end{array}$ & $\begin{array}{l}\text { Proses seleksi mengutamakan } \\
\text { kualitas. }\end{array}$ & Selama ini proses seleksi PPPK tidak bebas KKN. \\
\hline
\end{tabular}

dalam hal penyiapan calon guru melalui LPTK, tetapi lulusan LPTK tidak sertamerta dapat diangkat sebagai guru pemerintah. Seperti rekrutmen di Jepang dan Tiongkok, siapapun yang berminat dan memenuhi kriteria yang ditentukan dapat mendaftar dan mengikuti seleksi sebagai guru pemerintah.

Seleksi PPPK yang dilakukan saat ini merupakan upaya pemenuhan kebutuhan guru besar-besaran akibat banyak guru pensiun selama moratorium. Ke depan, seleksi guru hendaknya dapat dilaksanakan secara rutin dan terjadwal setiap tahun dengan mempertimbangkan kebutuhan guru akibat guru pensiun pada tahun tersebut. Seperti yang dilakukan di Jepang, rekrutmen yang rutin dan terjadwal akan lebih efektif untuk memastikan ketersediaan guru di sekolah.

\section{Penutup}

Seleksi dan rekrutmen guru melalui skema PPPK merupakan strategi untuk mengisi kekurangan guru yang tidak terdistribusi secara merata. Skema ini memberikan kesempatan bagi guru honorer yang tidak memenuhi syarat usia untuk mengi- kuti tes CPNS, namun tetap membuka persaingan dengan lulusan PPG yang tidak mengajar. Hal ini ditujukan untuk menyaring sumber daya manusia yang berkualitas dengan seleksi yang objektif dan berdaya saing. Masih adanya penolakan dari guru honorer, berakar dari sumber daya honorer yang memang direkrut tanpa mengikuti persyaratan kualifikasi guru nasional. Dengan rekrutmen PPPK mungkin banyak menjaring guru honorer, tetapi tidak menutup kemungkinan ada guru-guru honorer yang tidak lolos karena memang tidak memiliki kompetensi yang dibutuhkan sebagai guru. Padahal, mereka telah bekerja untuk jangka waktu yang panjang. Oleh karena itu, perbaikan seleksi dan rekrutmen menjadi penting untuk menghindari berlanjutnya permasalahan guru honorer ke depan.

Perbaikan total dalam sistem seleksi dan rekrutmen guru menjadi krusial dengan pertimbangan: (1) berdasarkan kebutuhan; (2) calon guru diproduksi oleh LPTK sesuai dengan kebutuhan di lapangan; serta (3) mengutamakan kompetensi dan kualifikasi. Rekrutmen guru PPPK yang diwacanakan Kemendikbud meru- 
pakan langkah awal untuk perbaikan kualitas masukan guru. Ketakutan akan tes dapat menjadi hambatan untuk menyaring guru yang benar-benar berkualitas sehingga perlu ada perbaikan dan penyesuaian metode pengukuran.

Selain itu, proses ini akan menyisakan guru-guru honorer yang tidak memenuhi kualifikasi yang disyaratkan, meskipun telah mengabdi bertahun-tahun. Pengabdian ini tidak boleh dilupakan dan harus dibenahi agar tidak berakibat buruk terhadap proses pembelajaran yang berlangsung. Sebaiknya pemerintah dapat membuat sistem konversi untuk menyesuaikan kualifikasi guru berdasarkan masa kerjanya. Konversi ini harus dilakukan secara objektif dan terukur, meskipun tidak melalui tes massal yang ditakutkan para guru honorer senior. Dengan adanya sistem konversi, pemerintah juga harus menghitung honor yang sepantasnya dan menjadikan ukuran tersebut sebagai patokan insentif bagi guru honorer. Pemerintah perlu menetapkan batasan upah minimum, jika masih menggunakan honorer. Jika tidak, pemerintah harus menghapus semua potensi mempekerjakan guru honorer dan mengganti dengan kebijakan seleksi guru ASN.

Masih absennya payung hukum mengenai pengelolaan guru perlu menjadi perhatian karena banyak permasalahan yang terjadi di lapangan tidak bisa diacu pada UUGD. Oleh karena itu, DPR RI perlu segera membahas RUU yang mengatur tentang guru untuk memberikan kepastian hukum bagi guru terkait pengelolaan sehingga dapat memastikan kualitas, distribusi, pengembangan hingga kesejahteraan guru. Dalam RUU yang mengatur tentang guru yang disiapkan oleh DPR $\mathrm{RI}$ perlu memuat seleksi guru khusus dan terbuka, peningkatan kesejahteraan guru, tata kelola, dan kewajiban mengajar guru di lokasi yang ditetapkan.

\section{Daftar Pustaka}

Abbas, H. (2020). Meluruskan arah pendidikan. Jakarta: Kompas Penerbit Buku.

Abdou, A. (2012). Teachers' recruitment and selection practices within different schooling systems in Egypt [Master's Thesis, the American University in Cairo]. AUC Knowledge Fountain. Diakses dari https://fount.aucegypt.edu/etds/1433

Alawiyah, F. (2018). Problematika tata kelola guru dalam implementasi undang-undang guru dan dosen. Aspirasi: Jurnal Masalahmasalah Sosial, 9(1), 121-143. doi: 10.46807/aspirasi.v9i1.1011

Arifa, F. N. (2020, Desember). PPPK guru sebagai pemenuhan kekurangan tenaga pendidik. Info Singkat, 12(23), 13-18. Diakses dari https://berkas.dpr.go.id/ puslit/files/info_singkat/Info\%20SingkatXII-23-I-P3DI-Desember-2020-1953.pdf

Armstrong, M. (2008). Strategic human resource management: a guide to action (4th Ed). London: Kogan Page. Diakses dari http://oktato.econ.unideb.hu/ kunandras/engMBA/SHRM/Armstrong_ SHRM_Action.pdf

Asian Development Bank. (2021). A diagnostic study of the civil service in Indonesia. Filipina: Asian Development Bank. doi:10.22617/TCS210016-2

Badan Keahlian DPR RI. (2019). Naskah akademik rancangan undang-undang tentang guru, Jakarta. Tidak diterbitkan.

Badan Kepegawaian Nasional. (2021, Januari 5). Dorong produktivitas birokrasi, pemerintah gulirkan skema PPPK bagi sejumlah jabatan ASN termasuk guru [Press release]. Diakses dari https://www. bkn.go.id/berita/dorong-produktivitasbirokrasi-pemerintah-gulirkan-skemapppk-bagi-sejumlah-jabatan-asntermasuk-guru

Badan Pusat Statistik. (2020). Potret pendidikan Indonesia: Statistik Pendidikan 2020. (Nomor Publikasi 04220.2002). Diakses dari https://www.bps.go.id/public ation/2020/11/27/347c85541c34e7dae543 95a3/statistik-pendidikan-2020.html 
Bahri. (2021, Januari 18). Dukungan APBD dalam Pemenuhan Kebutuhan Guru Daerah melalui Formasi PPPK [Paparan]. RDPU Komisi X DPR RI dengan Dirjen Guru dan Tenaga Kependidikan Kemendikbud, Dirjen Anggaran Kemenkeu, Dirjen Bina Keuangan Daerah Kemendagri, Deputi Bidang SDM Aparatur KemenPANRB, dan Kepala BKN. Jakarta. Tidak diterbitkan.

Badan Penelitian dan Pengembangan Kementerian Pendidikan dan Kebudayaan. (2017). Profesionalisme guru tidak tetap (GTT) di sekolah negeri. Jakarta: Pusat Penelitian Kebijakan Pendidikan dan Kebudayaan, Balitbang, Kemendikbud.

bin Syed Husin, S. M. (2020a). Malaysia national education blueprint: an overview on the policy of recruitment and selection of teachers. Journal of Economics, Finance and Management Studies (JEFMS), 3(3), 31-39. Diakses dari http://umpir.ump.edu. $\mathrm{my} / \mathrm{id} / \mathrm{eprint} / 28178$

bin Syed Husin, S. M. (2020b). Teacher recruitment, selection, and promotion: the role of teachers' unions in Malaysia. International Journal of Humanities Technology and Civilization (IJHTC), 8(1), 50-63. Diakses dari https://journal.ump. edu.my/ijhtc/article/view/4817

Cameron, V. \& Grootenboer, P. (2018). Human resource management in education: recruitment and selection of teachers. International Journal of Management and Applied Science, 4(2), 89-94.

Darmaningtyas, D. S. (2014, Desember). Rencana kebijakan moratorium penerimaan CPNS. Info Singkat, 6(24), 1720. Diakses dari http://berkas.dpr.go.id/ puslit/files/info_singkat/Info\%20SingkatVI-24-II-P3DI-Desember-2014-38.pdf

Francis, B., Hodgen, J., Craig, N., Taylor, B., Archer, L., Mazenod, A., Tereshchenko, A., \& Connolly, P. (2019). Teacher 'quality' and attainment grouping: the role of withinschool teacher deployment in social and educational inequality. Teaching and Teacher Education, 77(2019), 183-192. doi: 10.1016/j.tate.2018.10.001

Hobson, A. J., Ashby, P., Mclntyre, J., \& Malderez, A. (2010). International approaches to teacher selection and recruitment (OECD Education Working Papers, No. 47) France: OECD Publishing. http://dx.doi. org/10.1787/5kmbphhh6qmx-en

Ihsan, D. (2021, Februari 15). Guru honorer, pendaftaran PPPK dibuka Mei 2021. Kompas.com. Diakses dari https://www.kompas.com/edu/ $\mathrm{read} / 2021 / 02 / 15 / 163343171 / \mathrm{guru}-$ honorer-pendaftaran-pppk-dibuka-mei2021 ?page $=$ all

Indrawati, S. M. [Kemendikbud RI]. (2020, November 23). Pengumuman seleksi guru PPPK tahun 2021 [Video file]. Diakses dari https://www.youtube.com/ watch? $\mathrm{v}=\mathrm{EDUH} 43 \mathrm{a} 1 \mathrm{R} 7 \mathrm{c}$

Kamil, I. (2020, November 25). Menanti nasib pengangkatan 34.000 guru honorer yang Lulus PPPK 2019. Kompas.com. Diakses dari https://nasional.kompas. com/read/2020/11/25/07181941/menantinasib-pengangkatan-34000-guru-honoreryang-lulus-pppk-2019? page=all

Deputi Bidang SDM Aparatur KemenPANRB. [Parlemen Channel]. (2021, Januari 18). Live Streaming - RDP Komisi X DPR RI dengan Kemendikbud RI [Video file]. Diakses dari https://www.youtube.com/ watch?v=v2tICIRi7AE

Kementerian Pendidikan dan Kebudayaan. [Parlemen Channel]. (2021, Januari 18). Live Streaming - RDP Komisi X DPR RI dengan Kemendikbud $R I$ [Video file]. Diakses dari https://www.youtube.com/ watch?v=v2tICIRi7AE

Kementerian Pendidikan dan Kebudayaan. (2021, Maret, 5). Usulan terbesar sepanjang sejarah, pemda ajukan 568 ribu formasi guru ASN PPPK [Press Release]. Diakses dari https://www.kemdikbud.go.id/main/ blog/2021/03/usulan-terbesar-sepanjangsejarah-pemda-ajukan-568-ribu-formasiguru-asn-pppk

Kepala Badan Penelitian dan Pengembangan dan Perbukuan Kementerian Pendidikan dan Kebudayaan. (2021, Januari 18). Kajian latar belakang transformasi pendidik dalam peta jalan pendidikan Indonesia [Paparan]. RDPU Komisi X DPR RI dengan Dirjen Guru dan Tenaga Kependidikan Kemendikbud, Dirjen Anggaran Kemenkeu, Dirjen Bina 
Keuangan Daerah Kemendagri, Deputi Bidang SDM Aparatur KemenPANRB, dan Kepala BKN. Jakarta. Tidak diterbitkan.

Kementerian Pendidikan dan Kebudayaan. (tt). Rincian jumlah guru dan tenaga kependidikan menurut status kepegawaian \{Dashboard GTK\}. Diakses dari https:// referensi.data.kemdikbud.go.id/ dashboardptk/ptk_dash2.php?id=20, pada 15 Februari 2021

Komisi II berkeinginan lanjutkan revisi UU ASN. (2021). Diakses dari https://dpr.go.id/ berita/detail/id/31381/t/Komisi+II+Berkein ginan+Lanjutkan+Revisi+UU+ASN

Maharani, T. (2020, Desember 29). Kepala BKN: tak ada lagi pengangkatan Guru lewat seleksi CPNS. Kompas.com. Diakses dari https://nasional.kompas.com/ $\mathrm{read} / 2020 / 12 / 29 / 17194061 / \mathrm{kepala}-\mathrm{bkn}-$ tak-ada-lagi-pengangkatan-guru-lewatseleksi-cpns

Makarim, N. [Kemendikbud RI]. (2020, November 23). Pengumuman seleksi guru PPPK tahun 2021 [Video file]. Diakses dari https://www.youtube.com/ watch? $v=E D U H 43 a 1 R 7 c$

Numano, T. (2010, Februari 2021). Teacher training and certificate system. Diakses dari https://www.nier.go.jp/English/ educationjapan/pdf/201103TTCS.pdf

Organization for Economic Co-Operation and Development. (2005). Recruiting, selecting and employing teachers pointers for policy development. Diakses dari http://www. oecd.org/education/school/45399535.pdf

Pemerintah rekrut sejuta guru dengan sistem PPPK. (2021, Januari 7). Media Indonesia, hal. 2.

Potret Pendidikan. (2019, Agustus 24). Jebolan LPTK banyak nganggur atau pilih jadi guru honorer. PotretPendidikan.com. Diakses dari https://potretpendidikan.com/jebolanIptk-banyak-nganggur-atau-pilih-jadiguru-honorer/

Pramestuti, A. W. [Komisi X DPR RI Channel]. (2021, Mei 24). Pembukaan Rapat Dengar Pendapat Panja PTGKH-ASN Komisi X dengan Rektor Universitas Negeri Padang, Rektor Universitas Negeri Yogyakarta, Rektor Universitas Negeri Manado, dan
Rektor Universitas Pendidikan Ganesha. Live Streaming - RDP Komisi X DPR RI dengan Kemendikbud RI [Video file]. Diakses dari https://www.youtube.com/ watch?v=JkoFC_q38J4

Quin, D., Hemphill, S.A., \& Heerde, J.A. (2017). Associations between teaching quality and secondary students' behavioral, emotional, and cognitive engagement in school. Social Psychology Education, 20(4), 807829. doi: 10.1007/s11218-017-9401-2

Ree, J. D., Al-Samarrai, S., \& Iskandar, S. (2012). Sertifikasi guru di Indonesia: peningkatan pendapatan atau cara untuk meningkatkan pembelajaran? (Naskah Kebijakan No. 73264). Jakarta: Kemendikbud, Kingdom of Netherland, \& Bank Dunia. Diakses dari http:// documents1.worldbank.org/curated/ en/706731468259517603/pdf/732640BRI0 BAHA00disclosed0100170120.pdf

Revina, S. (2020, Oktober 21). Dampak sistem perekrutan dan pengembangan guru terhadap kualitas guru di Indonesia [Video file]. Diakses dari https://rise.smeru.or.id/ id/acara/membedah-sistem-perekrutandan-pengembangan-guru-tantangan-danstrategi-mewujudkan-pendidikan

Revina, S. \& Huang, A. (2020, Agustus 25). Proses rekrutmen sebagai ASN membuat guru di Indonesia berkualitas rendah. Program Rise di Indonesia. Diakses dari https://rise.smeru.or.id/id/blog/prosesrekrutmen-sebagai-asn-membuat-guru-diindonesia-berkualitas-rendah

Revina, S., Pramana, R. P, Fillaili, R., \& Suryadarma, D. (2020). Systemic constraints facing teacher professional development in a Middle-Income Country: Indonesia's experience over four decades (RISE Working Paper 20/054 Oktober 2020). Jakarta: RISE. Diakses dari https:// rise.smeru.or.id/sites/default/files/ publication/RISE_WP-054_Revinaetal.pdf

Rice, J. K. (2003). Teacher Quality: Understanding the effectiveness of teacher attributes. Economic Policy Institute. 1660 L Street, NW, Suite 1200, Washington, DC 20034. Diakses dari https://files.epi.org/ page/-/old/books/teacher_quality_exec_ summary.pdf 
Rosyidi, U. (2020, Desember 7). Jawaban PGRI terhadap pertanyaan tentang peta jalan pendidikan pada RDPU Komisi $X$ dengan PGRI [Paparan]. Rapat Dengar Pendapat Umum Komisi X tanggal 7 Desember 2020. Jakarta. Tidak diterbitkan.

Supriyatin. (2021). Penempatan PPPK guru 2019 di Kabupaten Wonosobo/ Pewawancara: Fieka Nurul A, Pusat Penelitian Badan Keahlian DPR RI, Jakarta.

Suryani, N. (2020, Oktober 21). Strategi pemerintah pusat dalam mengatasi tantangan pengembangan guru [Paparan]. Forum Kajian Pembangunan tentang Membedah Sistem Perekrutan dan Pengembangan Guru: Tantangan dan Strategi Mewujudkan Pendidikan Berkualitas. Jakarta, The Smeru Research Institute. Tidak diterbitkan.

Xu, Z. \& Gulosino, C. (2006). How does teacher quality matter? the effect of teacherparent partnership on early childhood performance in public and private schools. Education Economics, 14(3), 345-367. doi: 10.1080/09645290600777550

Yamasaki, H. (2016). Teachers and teacher education in Japan. Bull. Grad. School Educ. Hiroshima Univ., 65(3), 19-28. 


\section{Lampiran}

Tabel Aspirasi tentang Penerimaan PPPK dari KSASN, GTKHNK 35+ dan SNWI

\begin{tabular}{|c|c|c|c|}
\hline Isu & KSASN & GTKHNK 35+ & SNWI \\
\hline Kualifikasi & $\begin{array}{l}\text { Tidak bisa disamakan dengan } \\
\text { buruh biasa karena minimal S-1. }\end{array}$ & $\begin{array}{l}\text { - Guru di daerah tertentu (3T) } \\
\text { tidak ada yang S-1. Guru } \\
\text { honorer sulit untuk melanjutkan } \\
\text { ke S-1 karena kendala geografi. }\end{array}$ & \\
\hline $\begin{array}{l}\text { Status } \\
\text { Kepegawaian }\end{array}$ & $\begin{array}{l}\text { - Pendidik dan tenaga } \\
\text { kependidikan harus memiliki } \\
\text { status kepegawaian yang jelas } \\
\text { - Guru PNS bisa mendiskriminasi } \\
\text { guru honorer. }\end{array}$ & $\begin{array}{l}\text { - Menyelesaikan permasalahan } \\
\text { guru dan tenaga kependidikan } \\
\text { honorer non-kategori khususnya } \\
\text { yang berusia tiga puluh lima } \\
\text { tahun ke atas dari sekolah- } \\
\text { sekolah negeri semua jenjang. } \\
\text { - Minta Keppres PNS tanpa tes } \\
\text { sebagaimana yang pernah } \\
\text { diberikan kepada bidan dan } \\
\text { perangkat desa. } \\
\text { - Tidak terdaftar sebagai Honorer } \\
\text { K2. } \\
\text { - Guru honorer adalah tenaga } \\
\text { fungsional bukan struktural jadi } \\
\text { tidak cocok untuk dikontrak. }\end{array}$ & $\begin{array}{l}\text { Guru honorer } \\
\text { diangkat } \\
\text { menjadi guru } \\
\text { PNS tanpa tes. }\end{array}$ \\
\hline $\begin{array}{l}\text { Kesejahteraan } \\
\text { guru }\end{array}$ & $\begin{array}{l}\text { Perlu memperhatikan } \\
\text { kesejahteraan pendidik dan } \\
\text { tenaga kependidikan yang } \\
\text { berstatus non-ASN. }\end{array}$ & $\begin{array}{l}\text { - Tidak semua guru honorer } \\
\text { mungkin lulus tes maka akan } \\
\text { tetap ada guru honorer yang } \\
\text { tidak digaji dengan layak. } \\
\text { - Kesejahteraan berhubungan } \\
\text { dengan kualitas guru. }\end{array}$ & \\
\hline
\end{tabular}

\begin{tabular}{|c|c|c|c|}
\hline Masa kerja & $\begin{array}{l}\text { Perlunya regulasi tenaga pendidik } \\
\text { dan tenaga kependidikan non- } \\
\text { ASN dengan memperhatikan } \\
\text { masa kerja. }\end{array}$ & Diangkat setelah 2005. & \\
\hline Payung hukum & $\begin{array}{l}\text { Perlu revisi total UU ASN dengan } \\
\text { asas keadilan. }\end{array}$ & & $\begin{array}{l}\text { Meminta revisi } \\
\text { UU ASN. }\end{array}$ \\
\hline Sertifikasi & $\begin{array}{l}\text { Guru honorer terhambat karena } \\
\text { perlu SK kepala daerah. }\end{array}$ & & \\
\hline Uji Kompetensi & $\begin{array}{l}\text { Guru honorer memiliki } \\
\text { pengalaman mengajar lebih lama, } \\
\text { sebaiknya tidak dites dengan tes } \\
\text { kompetensi (pedagogik, dsb.) } \\
\text { karena sulit bersaing dengan fresh } \\
\text { graduate. }\end{array}$ & $\begin{array}{l}\text { Tidak bisa lagi ikut tes CPNS } \\
\text { karena diatas } 35 \text { tahun. }\end{array}$ & \\
\hline $\begin{array}{l}\text { Penerimaan } \\
\text { PPPK }\end{array}$ & & $\begin{array}{l}\text { - Usulan dari daerah tidak } \\
\text { mencakup jumlah seluruh } \\
\text { guru honorer. Jangan sampai } \\
\text { formasi yang dibuka lebih sedikit } \\
\text { daripada posisi yang sudah diisi } \\
\text { oleh honorer. } \\
\text { - Masa kerja guru honorer menjadi } \\
\text { tidak dihargai. } \\
\text { - Guru TK belum diakomodasi } \\
\text { dalam penerimaan PPPK. } \\
\text { - Ada kepentingan personal dalam } \\
\text { seleksi PPPK. }\end{array}$ & $\begin{array}{l}\text { Mengapa tidak } \\
\text { ada formasi } \\
\text { untuk guru } \\
\text { agama? }\end{array}$ \\
\hline
\end{tabular}

